\title{
Article \\ Damage to Residual Trees in Thinning of Broadleaf Stand by Mechanised Harvesting System
}

\author{
Branko Ursić, Dinko Vusić *, Ivica Papa (D), Tomislav Poršinsky, Željko Zečić and Andreja Đuka (D)
}

check for

updates

Citation: Ursić, B.; Vusić, D.; Papa, I.; Poršinsky, T.; Zečić, Ž.; Đuka, A. Damage to Residual Trees in Thinning of Broadleaf Stand by Mechanised Harvesting System. Forests 2022, 13, 51. https://doi.org/ 10.3390/f13010051

Academic Editors: Giuseppe Zimbalatti, Bruno Bernardi and Andrea R. Proto

Received: 11 December 2021 Accepted: 30 December 2021 Published: 3 January 2022

Publisher's Note: MDPI stays neutral with regard to jurisdictional claims in published maps and institutional affiliations.

Copyright: (c) 2022 by the authors Licensee MDPI, Basel, Switzerland. This article is an open access article distributed under the terms and conditions of the Creative Commons Attribution (CC BY) license (https:// creativecommons.org/licenses/by/ $4.0 /)$.

\author{
Faculty of Forestry and Wood Technology, University of Zagreb, Svetošimunska cesta 23, 10002 Zagreb, Croatia; \\ bursic@sumfak.unizg.hr (B.U.); ipapa@sumfak.unizg.hr (I.P.); tporsinsky@sumfak.unizg.hr (T.P.); \\ zzecic@sumfak.unizg.hr (Ž.Z.); aduka@sumfak.unizg.hr (A.Đ.) \\ * Correspondence: dvusic@sumfak.unizg.hr
}

\begin{abstract}
This research was conducted to determine the cause, intensity and location of damage (stem, butt end, root collar, root) and the extent of damage to standing trees during felling and processing by an harvester and timber extraction by a forwarder (cut-to-length system). The research was conducted in the central part of the Republic of Croatia in the Management Unit (MU) "Bjelovarska Bilogora" during the thinning of Subcompartment 14b, area of 18.28 ha, in the stand of hornbeam (Carpino betuli-Quercetum roboris fagetosum Rauš 1975), age 70, and of Subcompartment 14c, area of 9.07 ha, in a stand of common beech (Carici pilosae-Fagetum Oberdorfer 1957) aged 79 years. The thinning intensity was $12.13 \%$ in Subcompartment $14 \mathrm{~b}$ and $13.72 \%$ in Subcompartment $14 \mathrm{c}$. Field measurements were carried out on sample plots-the first time in 2017 to determine the intensity and characteristics of the damage to standing trees with regard to the cause of the damage (harvester or forwarder), and the second time in 2018 to determine the overall intensity and features of the damage to standing trees after finishing harvesting operations. For all trees remaining in the stand after the harvesting operations, the following were determined: tree species, diameter at breast height $(D B H)$, the position of the tree in the stand depending on the forest traffic infrastructure, and-if damaged - cause of damage, type of damage, the position of damage on the tree, and dimensions of damage. The intensity of the damage was expressed by the ratio of damaged and undamaged trees, with a detailed analysis of bark damage (squeezed-bark damage and peeled-bark injuries). The results of the research indicate the highest prevalence of peeled-bark injuries. In relation to the total number of standing trees, trees with peeled-bark injuries were more represented in Subcompartment $14 \mathrm{c}$ (39\%) than in Subcompartment 14b (33\%). In Subcompartment 14b, the harvester and the forwarder damaged an equal number of trees, while in Subcompartment 14c, the harvester damaged 59\% of the damaged trees. In both subcompartments, an average of $83 \%$ of (peeled bark) injuries were up to $1.3 \mathrm{~m}$ above the ground. In both subcompartments, the most common (67\%) were injuries up to $100 \mathrm{~cm}^{2}$ in size, for which many authors claim the tree can heal by itself. Given the increasing use of harvester-forwarder systems in deciduous stands and research results that indicate possible damage to standing trees, it is necessary to pay attention to all phases of planning and execution of timber harvesting operations, thus minimising negative effects.
\end{abstract}

Keywords: bark damage; harvester; forwarder

\section{Introduction}

Thinning as a treatment is a procedure that, with the help of positive selection, systematically directs the growth and development of selected trees, shapes the optimal structure of the stand following management goals, increases the quality, stability, and vitality of the stand, and prepares stands for natural regeneration [1]. In addition, the thinning removes one part of the increment accrued from the previous thinning that makes the removal of intermediate felling volume [2]. Thus, each stand, managed according to even-aged principles, is exposed to thinning several times during its rotation period. In addition to the 
principles of thinning, it is to be expected that the future quality of timber also be affected by the quality of performed harvesting operations. Although silvicultural operations (such as thinning) are performed to achieve positive management goals, timber harvesting operations can negatively affect forest stands, which is primarily reflected in the damage of forest soil and the remaining trees [3].

Damage to the stand can be defined as mechanical damage to the total number of standing trees in the stand after finishing operations [4]. Damage to standing trees can occur directly (mechanically) and afterwards indirectly (biologically). Previous researchers have pointed to the fact that the number of mechanically damaged trees can serve as a good indicator of the total damage to the stand [5-7]. In addition, such damage can be determined relatively easily and accurately [3].

The amount and characteristics of damage to standing trees in harvesting operations are influenced by numerous factors that can be classified into three groups: 1. working conditions; 2 . choice of methods and means of work; and 3. practitioner's attitude towards harvesting operations [8]. Working conditions, which are the most varying, can change in part depending on the goals of management. These include: the felling intensity expressed by the number of trees per unit area $[9,10]$; the felling season, with less damage occurring during winter felling, making it preferable [11]; the density of primary and secondary transport infrastructure on which the average extraction distance depends [12]; and terrain slope [13]. Damage to the remaining stand can be caused by both felling and extracting, regardless of the technological level of the machines or the experience of the operators [14]. However, the amount and characteristics of damage depend on the combination of means and methods used in timber harvesting operations [15], whose choice is directly related to the level of planning [13], but is also limited by various working conditions. A practitioner's attitude towards harvesting operations depends on his/her experience and skills [16] and the interest of each individual in the quality of the work performed [4].

Attention should be paid not only to damage to the stand during operations, but also to the efficiency of harvesting operations. Commonly used harvesting systems in Croatia imply the use of chainsaws. The application of fully mechanised timber harvesting systems results in increased productivity, reduced physical workload, and increased work safety [17]. Efforts to rationalise and develop methods and systems of timber harvesting operations should minimise environmental effects such as damage to standing trees and forest soil [11]. When thinning is fully mechanised, it becomes technically complex, with high costs due to reduced vehicle mobility within the forest caused by limited space between trees [18], which leads to reduced productivity and increased costs [19].

The latest research on harvester application in broadleaf-dominated stands indicates different challenging factors in different European regions [20]. Since the introduction of the first privately owned harvester in Croatia in 2005 [21], the number of harvesters working in Croatia has reached 40 in 2021, four of which are owned by the state company Croatian Forests Ltd. (which manages $73 \%$ of the total forest area with a net annual cut of $5.4 \mathrm{mil} \mathrm{m}^{3}$ ) and another four by Slovenian entrepreneurs working in Croatian territory [20]. They all work in both private and state forests, mostly in conifer plantations, stand sanitation after forest fires, clear-cuts of European black pine (Pinus nigra Arn.), stands ready for conversion, clear-cuts in poplar (Populus sp.) plantations, and sanitation felling of narrow-leaved ash stands due to ash dieback caused by Hymenoscyphus fraxinues (T. Kowalski) Baral, Queloz \& Hosoya, but also in late thinnings and preparatory fellings of hardwood stands, often in combined mechanised and motor-manual cutting due to larger butt swelling, large crowns and thick branches [20].

A further increase in the use of fully mechanised systems is expected due to labour shortages and a needed increase in labour productivity [17], but mechanised forest operations in close-to-nature forestry are generally more complex than those in conventional conifer monoculture, and often lead to lowered harvesting productivity [22]. Although some studies indicate that a higher degree of mechanization causes a higher intensity of damage [15], application of the cut-to-length system, which includes a combination of 
an harvester and a forwarder, causes less damage to the forest, slower accumulation of damaged trees over time, and better distribution of accumulated damage in the stand, which ultimately increases the stability of the stand and the timber quality at the end of the management period when compared with the application of motor-manual felling and timber extraction by skidders in the tree-length and full-tree harvesting methods [23,24].

Current information on damage to residual trees following fully mechanised harvesterforwarder systems is primarily focused on young coniferous stands reporting 29.1-36.1\% damaged trees, but with a mean wound area under $100 \mathrm{~cm}^{2}$ in the thinning of a 12-year old Pinus taeda stand with a removal of $40 \%$ of trees in the stand [25], and 25\% damaged trees in the first thinning of Pinus taeda stand with a removal of $50 \%$ of trees in the stand [26], to as low as $7.0 \%$ (with a $1 \mathrm{~cm}^{2}$ bark damage threshold) in the first thinning with an intensity of $60 \%$ of the standing trees in Norway spruce dominated stand without previous marking of trees designated for felling, and 3.2\% when prior marking of the trees was conducted [27]. Mechanised thinning of an uneven-aged Norway spruce dominated stand resulted in $21.5 \%$ damaged trees [28]. Late thinnings resulted in damage in $37.4 \%$ of the remaining trees in a mixed conifer stand [29] and shelterwood system regeneration felling (with 18.6 and $17 \%$ intensity) of a sessile-oak-dominated stands resulted in 20.47 and $23.36 \%$ damaged trees [30].

Depending on the intensity of the damage, further development of the stand is indirectly jeopardised if the damage to the remaining trees is such that the stability and vitality of the stand are impaired. In contrast, the intensity of the damage has a direct impact on the quality of the remaining trees, thus reducing the economic value of such stands [31]. Certainly, the quality of the timber volume at the end of the rotation period is most affected by those negative effects that occurred during forest growth, i.e., from a young age and especially during thinnings, and whose shortcomings are most pronounced at the end of the rotation period.

The question of how and to what extent injuries affect tree development has been the subject of numerous studies. Research on stand damage has investigated the extent of damage to the trees and its impact on further tree growth. As a general rule, fungal infection is not expected in the case of superficial bark damage, as in the case of peeled bark up to the size of $10 \mathrm{~cm}^{2}$, while the possibility of fungal infection increases with increasing damage to the surface area [32-34]. However, several research results indicate that even injuries of up to $100 \mathrm{~cm}^{2}$ can be repaired independently by the tree itself $[32,34,35]$, and report that no fungi have been identified on such injuries [34]. The limiting value of the size of the critical injury can be approximated as the square of the diameter at the breast height of the tree [36], but the size of the area considered critical for a peeled-bark injury, which causes tree death, also depends on tree species, age, genetic predispositions, location of the injury, dimensions, and the shape of the injury (round, transverse or longitudinal) with respect to the longitudinal axis of the tree [37,38]. In addition to the size of the injury, the occurrence of fungal infection is also affected by the height of the injury from the soil, as it was found that the optimal conditions for fungal development are up to one meter from the ground [34], and the closer the injuries are to the ground, the more favourable the conditions created for the development of wood-destroying mycoses [37].

The negative consequences of damaged trees can lead to increment loss of $1-4.7 \%$ [34], and up to $8.1 \%$ loss in a mixed beech stand [39]. The loss of increment with a decrease in the quality of timber assortments results in a decrease in the economic value of stands [31,40]. For example, damage to beech bark results in air entering the wood cells, which eventually creates a specific white rot [41] that also reduces the technical value of the wood. Injuries to trees in the form of peeled bark can cause the appearance of various wood defects (colour change, frost crack, ring shake, heart shake, buckle, rot), which reduce the value of future roundwood [42-44].

In some countries, legal regulations prescribe the maximum allowable damage to standing trees. For example, in Finland, the maximum damage allowed is $15 \%$ of the 
remaining trees, while in Poland, the damage is allowed on 5\% of the remaining trees [23] in the stand.

Given that there is growing concern to increase the quality of timber harvesting operations in order to reduce their negative effects on forest ecosystems, it is necessary to determine the consequences of the operations performed and identify and record the causes [45].

This research aims to determine the quality of fully mechanised harvesting operations (harvester-forwarder) with an emphasis on determining the origin (harvester or forwarder), location (stem, butt end, root collar, root), and the size of individual damage to the remaining standing trees after harvesting concerning their position in the stand.

\section{Materials and Methods}

The research was conducted in a 27.34 ha felling site located in the Forest Administration (FA) Bjelovar, Management Unit (MU) "Bjelovarska Bilogora", consisting of Subcompartments $14 \mathrm{~b}$ and $14 \mathrm{c}\left(\varphi 45^{\circ} 59^{\prime} 59^{\prime \prime} \mathrm{N}\right.$ and $45^{\circ} 59^{\prime} 31^{\prime \prime} \mathrm{N}$ and $\lambda 16^{\circ} 44^{\prime} 05^{\prime \prime} \mathrm{E}$ and $\left.16^{\circ} 43^{\prime} 38^{\prime \prime} \mathrm{E}\right)$ of state forests managed by the company "Croatian Forests" Ltd. (Figure 1, Table 1).

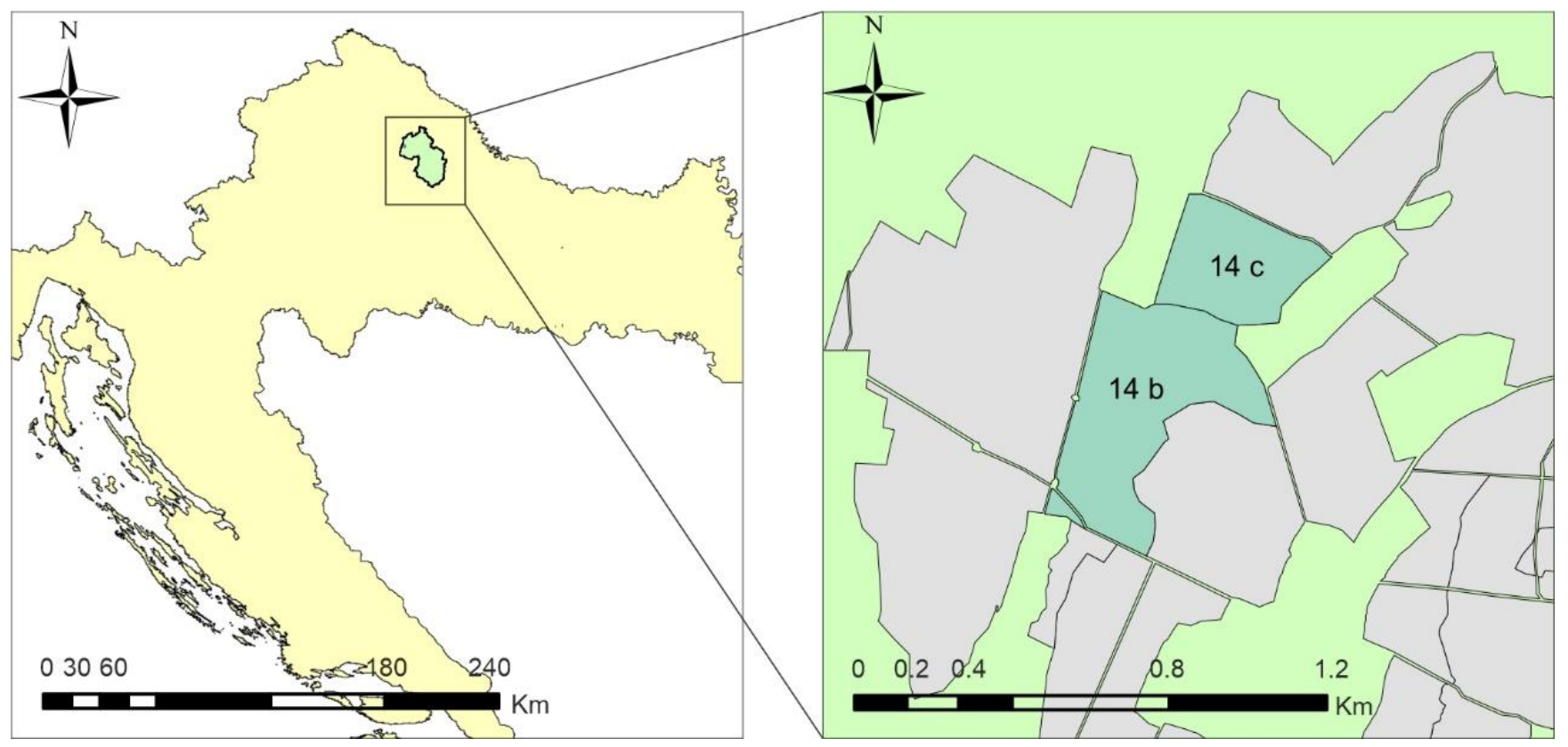

Figure 1. Study area.

On the south-west part of Subcompartment 14b (Figure 2), a landing site was positioned along the forest road of a total length of $545 \mathrm{~m}$, while a secondary traffic infrastructure network in the researched subcompartments consisted of $3.46 \mathrm{~km}$ of trails $(126.5 \mathrm{~m} / \mathrm{ha})$ and $8.51 \mathrm{~km}$ of harvester "ghost trails" (311.2 m/ha).

The prescribed thinning intensity in both subcompartments was around $11 \%$ of the standing volume, amounting to $34.03 \mathrm{~m}^{3} /$ ha in Subcompartment $14 \mathrm{~b}$ and $44.98 \mathrm{~m}^{3} / \mathrm{ha}$ in Subcompartment 14c. The thinning intensity per tree species amounted to $2.02 \mathrm{~m}^{3} / \mathrm{ha}$ of European beech and $32.00 \mathrm{~m}^{3}$ /ha of European hornbeam in Subcompartment 14b, while in Subcompartment $14 \mathrm{c}$ thinning intensity of European beech was $19.96 \mathrm{~m}^{3} / \mathrm{ha}$ and $25.03 \mathrm{~m}^{3} /$ ha of European hornbeam. 
Table 1. Data on surveyed subcompartments.

\begin{tabular}{|c|c|c|}
\hline Subcompartment & $14 b$ & $14 \mathrm{c}$ \\
\hline Area, ha & 18.28 & 9.07 \\
\hline Age/Rotation, years & $79 / 100$ & $79 / 100$ \\
\hline Altitude, $\mathrm{m}$ & 100 & $150-175$ \\
\hline Aspect & Western & Southwestern \\
\hline Inclination, \% & $3-9$ & $3-9$ \\
\hline Soil & Luvisol & Luvisol \\
\hline Phytocenosis & $\begin{array}{c}\text { Carpino betuli-Quercetum roboris } \\
\text { fagetosum Rauš } 1975\end{array}$ & Carici pilosae_Fagetum Oberdorfer 1957 \\
\hline Canopy coverage & Complete & Complete \\
\hline Stocking & 1.23 & 1.06 \\
\hline Growing stock, $\mathrm{m}^{3}\left(\mathrm{~m}^{3} / \mathrm{ha}\right)$ & $5530(291.58)$ & $3681(405.84)$ \\
\hline Species composition, $\mathrm{m}^{3} /$ ha $(\%)$ & $\begin{array}{c}\text { European hornbeam } \\
\text { (Carpinus betulus L.) } 243.71 \text { (84) } \\
\text { Pedunculate oak } \\
\text { (Quercus robur L.) } 18.16(6) \\
\text { European beech } \\
\text { (Fagus sylvatica L.) } 17.34(6) \\
\text { Sessile oak (Quercus petraea } \\
\text { (Matt.) Liebl.) } 3.72 \text { (1) } \\
\text { Black alder (Alnus glutinosa (L.) } \\
\text { Gaertn.) 8.32 (3) } \\
\text { Other hard broadleaves } 0.33\end{array}$ & $\begin{array}{c}\text { European beech } \\
\text { (Fagus sylvatica L.) } 201.76(50) \\
\text { European hornbeam } \\
\text { (Carpinus betulus L.) } 179.60(44) \\
\text { Sessile oak (Quercus petraea } \\
\text { (Matt.) Liebl.) } 16.54(4) \\
\text { Pedunculate oak } \\
\text { (Quercus robur L.) } 7.94(2)\end{array}$ \\
\hline Number of trees, $\mathrm{N} / \mathrm{ha}$ & 784 & 540 \\
\hline Basal area, $\mathrm{m}^{2} /$ ha & 28.88 & 30.98 \\
\hline Mean tree, $\mathrm{cm}$ & 21.60 & 30.98 \\
\hline Annual increment, $\mathrm{m}^{3} / \mathrm{ha}$ & 7.49 & 9.70 \\
\hline
\end{tabular}

The harvesting system previously applied in the researched subcompartments consisted of felling and processing by chainsaws and timber skidding. To enable the in-site travel of the harvester (and forwarder) and its reaching of the marked trees (and processed roundwood), it was necessary to establish a network of secondary transport infrastructure. Therefore, a correction of the tree selection and marking (for previously planned motormanual timber harvesting) was performed in such a way as to include the trees located on the future "ghost trails". This resulted in omitting part of the previously marked trees to retain the prescribed felling intensity (Table 2). According to the technical characteristics of the harvester, the "ghost trails" were placed at a 20-meter distance. This enabled felling and processing of the trees situated between the "ghost trails" parallel to the felling and processing of the trees located on the "ghost trails" and the forwarding of the processed roundwood. Timberjack machines, forwarder model 1710D, and harvester model 1470D were used; the technical characteristics are shown in Table 3. Harvesting was conducted during summertime, and the absence of precipitation allowed favourable vehicle mobility. 


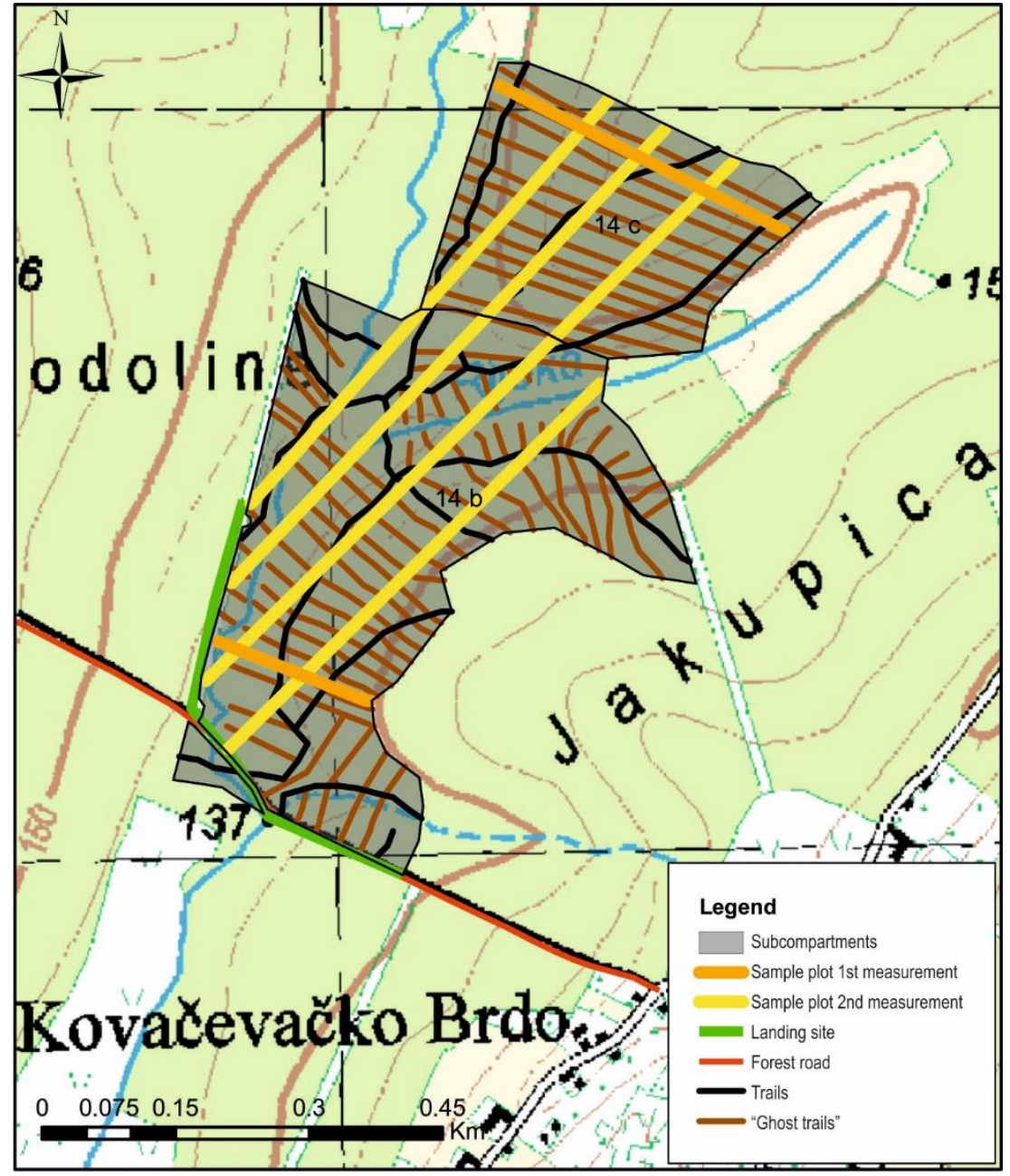

Figure 2. Sample plots.

Table 2. Data on trees marked for felling.

\begin{tabular}{ccccc}
\hline Subcompartment & \multicolumn{2}{c}{ 14b } & \multicolumn{2}{c}{ 14c } \\
\hline & $\begin{array}{c}\text { Motor-manual felling } \\
\text { and processing }\end{array}$ & $\begin{array}{c}\text { Mechanised felling } \\
\text { and processing }\end{array}$ & $\begin{array}{c}\text { Motor-manual felling } \\
\text { and processing }\end{array}$ & $\begin{array}{c}\text { Mechanised felling } \\
\text { and processing }\end{array}$ \\
\hline Number of trees, $\mathrm{N}$ & 1455 & 1782 & 423 & 559 \\
\hline Removal, $\mathrm{m}^{3}$ & 741.81 & 731.24 & 407.02 & 446.3 \\
\hline Thinning intensity, $\%\left(\mathrm{~m}^{3} / \mathrm{ha}\right)$ & $13.92(40.58)$ & $13.72(40.00)$ & $11.06(44.88)$ & $12.13(49.21)$ \\
\hline Average $\mathrm{DBH}, \mathrm{cm}$ & & 21.7 & & 26.4 \\
\hline Average volume, $\mathrm{m}^{3} /$ tree & 0.51 & 0.41 & 0.96 & 0.80 \\
\hline
\end{tabular}

Table 3. Technical characteristics of the machines.

\begin{tabular}{ccc}
\hline & Harvester Timberjack 1470D & Forwarder Timberjack 1710D \\
\hline Length, $\mathrm{mm}$ & 7700 & 10,900 \\
Height, $\mathrm{mm}$ & 3730 & 3900 \\
Width, $\mathrm{mm}$ & 3000 & 3050 \\
Weight, $\mathrm{kg}$ & 18,800 & $18,500-19,500$ \\
Payload, $\mathrm{kg}$ & - & 17,000 \\
\hline
\end{tabular}


Collecting the stand data, as well as determining, classifying and recording the damage to the trees, were performed following the content and structure of the recording sheets based on the concept proposed in previous research [5], but while taking into account the specifics of a fully mechanised timber harvesting system.

Field data collection was performed on two occasions, the first time during the timber harvesting and the second time after the harvesting work had been completed.

The first field survey was carried out twice in July 2017 in each subcompartment along one "ghost trail" (sample plots painted orange on the map, Figure 2). The first time was immediately after the work of the harvester and the second time immediately after the work of the forwarder, so that the recorded damages could be classified according to the cause concerning the means of work. During the measurement after the harvester operation, all damage was spray-painted to avoid recording one damage twice (Figure 3). In addition, tree species, diameter at breast height $(D B H)$, type of damage, the position of damage on the tree, and the dimensions of damage were recorded for all damaged trees. The sample "ghost trail" length was $170 \mathrm{~m}$ in Subcompartment $14 \mathrm{~b}$ and $340 \mathrm{~m}$ in Subcompartment 14c.

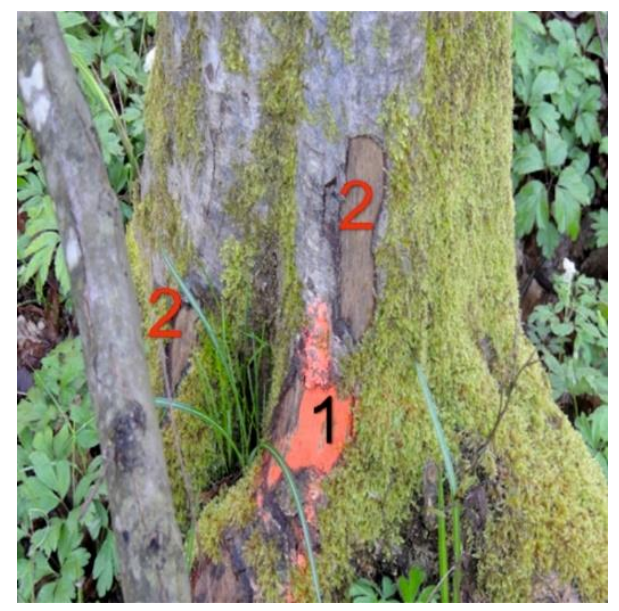

Figure 3. Damage recording (1: harvester-caused; 2: forwarder-caused).

The second field survey was conducted in March and April 2018 on four sample plots (transects) in Subcompartment 14b and three sample plots in Subcompartment 14c (sample plots painted yellow on the map, Figure 2). To achieve a representative survey result, a survey intensity of $10 \%$ was selected, which was, for example, prescribed for the forest management surveys on transect lines for stands above 2/3 of the rotation [46]. In Subcompartment 14b, the sample area was $1.83 \mathrm{ha}$, and in Subcompartment 14c, 0.91 ha. The total length of the sample plots in Subcompartment $14 \mathrm{~b}$ was $1830 \mathrm{~m}$, and in Subcompartment $14 \mathrm{c}, 828.1 \mathrm{~m}$. The sample plots (transects) were placed at a distance of $50 \mathrm{~m}$ from each other to achieve the required sampling intensity for the width of the transects $(10 \mathrm{~m})$ and the subcompartment area. Considering that the processing and bunching, and thus the transport of the roundwood, took place mainly on "ghost trails", it was expected that the trees next to the "ghost trails" would be the most damaged; the transects were therefore placed in such a way as to vertically intersect the "ghost trails". Since the "ghost trails" in the stand were placed at an approximate angle of $135^{\circ}$, it was necessary to place the transects at an azimuth of $45^{\circ}$, thus enabling a representative coverage of the "ghost trails" and part of the stand between them. For all remaining trees after thinning, which were located on the transects, the second field survey had to determine and measure the following parameters: tree species, $D B H$, tree position, and-additionally for damaged trees-type of damage, tree damage position, and dimensions of damaged bark. The position of the tree was determined by its spatial position relative to the secondary transport infrastructure. According to their position, they were recorded as: (1) tree next to the "ghost trails" (trees 
that were in close proximity to the "ghost trails"); (2) tree next to the main forwarding trail (trees that were in the close proximity to the main forwarding trail); and (3) all other trees.

During both field surveys for damaged trees, it was necessary to determine the type of damage, defined as: (1) uprooted and/or broken tree, (2) broken branches on the tree, (3) squeezed bark or peeled tree bark. Squeezed bark meant surface damage to the outer dead part of the bark, and peeled bark meant a form of bark injury in which the cambium zone was visible. The method of determining the position of individual damage to the tree was performed following previous research, and is shown in Figure 4a [3,32]. As shown in Figure 4a, damage was classified as: (1) damage to the stem (if the damage was above $1.3 \mathrm{~m}$ from the ground); (2) damage to the butt end (if it was $0.3-1.3 \mathrm{~m}$ from the ground); (3) damage to the root collar (if located up to $0.3 \mathrm{~m}$ from the ground and at a distance of up to $0.2 \mathrm{~m}$ from the edge of the stem); and (4) root damage (if it was further than $0.2 \mathrm{~m}$ from the edge of the stem) [3]. The magnitude of the bark damage, i.e., the dimensions of the damage, was measured so that the shape of the damage would be approximated with a regular quadrilateral. Therefore, the length and width of each injury were measured (Figure 4).
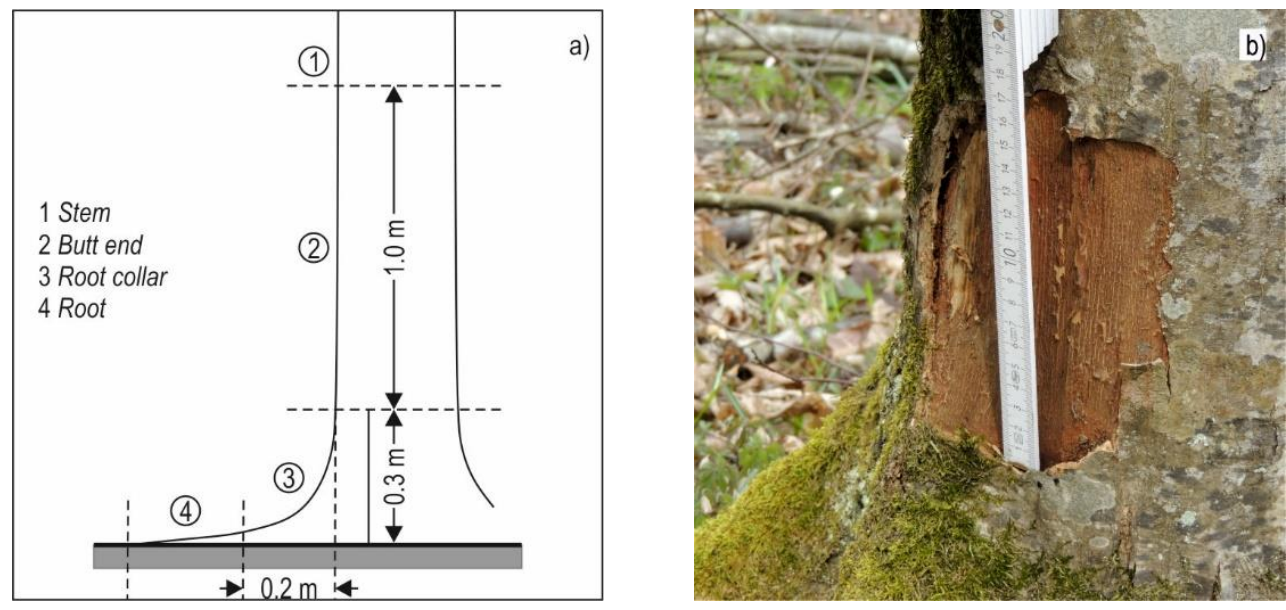

Figure 4. (a) Determining the position of an individual injury on a tree; (b) Measurement of injury dimensions.

The entry and computer processing of the collected data was performed using MS Excel and Statistica. In MS Excel, based on the collected data, the area of damaged bark was calculated for individual damage. The areas of peeled bark, as the most common form of damage, were summed at the level of each injury position on the tree and at the level of one tree. Statistical data processing referred to testing the size of peeled-bark injuries (individually and per tree) by $t$-test to investigate: (1) the impact of the subcompartment or the impact of stand factors (a) in the work of harvester and (b) in the work of forwarder; (2) the impact of the machine in the same stand conditions; and (3) the influence of stand conditions in the group work of harvester and forwarder. An analysis of the variance and a Scheffé post hoc test of the influence of the tree location on the total area of peeled-bark injury per tree and the position of the injury on the tree were performed.

\section{Results}

\subsection{Results of the First Field Survey}

According to the cause of the damage to the tree in Subcompartment 14b, the harvester and forwarder-caused damage to the same number of trees, and together damaged 60 trees. In contrast, the number of trees damaged by the harvester in Subcompartment 14c was higher by approximately 18\% (37 trees were damaged by the harvester and 26 trees by the forwarder). 
In Subcompartment 14c, 70 individual peeled-bark injuries were recorded following the work of the harvester, which primarily occurred on the butt end (56\%), root collar (24\%), and stem (20\%). In Subcompartment 14b, 56 individual peeled-bark injuries were recorded, primarily on the root collar $(57 \%)$, while other injuries were distributed on the butt end $(32 \%)$ and stem (11\%).

During the work of the forwarder, there was no significant deviation in the position of individual peeled-bark injuries between the subcompartments investigated. During the work of the forwarder in Subcompartment 14b, 58 peeled-bark injuries occurred, and the largest share of them was present on the root collar (55\%), then on the butt end (33\%), root $(7 \%)$, and stem (5\%). In Subcompartment 14c, during the work of the forwarder, 44 peeled-bark injuries occurred, and they were most common on the root collar (59\%), then on the butt end $(32 \%)$ and stem $(9 \%)$.

$T$-test statistical parameters of the influence of stand conditions on the size of individual peeled-bark injuries and the sum of the injury area by the position on a tree are shown in Table A1 for the harvester operation and Table A2 for the forwarder operation. A statistically significant influence $(t=-2.43, p=0.0190)$ of stand conditions on the size of individual peeled-bark injuries on the root collar during the harvester operation (Table A1) was determined. According to the $t$-test results, stand conditions did not affect the size of the peeled-bark injury during the forwarder operation (Table A2).

In Subcompartment 14b, a statistically significant influence of the means of work on the size of the individual root collar peeled-bark injury $(\mathrm{t}=-2.9909, p=0.0040)$ and on the sum of the peeled-bark injury area on the root collar $(\mathrm{t}=-2.8467, p=0.0068)$ was determined. On average, the forwarder-caused a $146 \mathrm{~cm}^{2}$ larger individual root collar bark injury (or $254 \mathrm{~cm}^{2}$ summed at the tree level) (Table A3).

\subsection{Results of the Second Field Survey}

A total of 1090 trees were recorded on transects (sample plots) in both subcompartments, of which 387 had at least one form of damage. As the most common type of damage, peeled bark, was analysed in detail and presented in the research results. The second most common type of damage, but of much lower intensity, was squeezed bark, while other types of damage (uprooted and/or broken tree, broken branches) were almost non-existent. A total of 290 damaged trees was recorded in Subcompartment 14b. Of these, one tree was broken, one had broken branches and peeled bark, 21 had squeezed bark, of which 16, in addition, had a peeled-bark injury, and 267 had only peeled bark. A total of 97 damaged trees was recorded in Subcompartment 14c. Of these, one tree was broken, 25 had squeezed bark, of which 20 had a peeled-bark injury as well, and 71 had only peeled-bark injuries.

\subsubsection{Squeezed-Bark Damage}

A total of 29 squeezed-bark injuries were recorded on 21 trees in Subcompartment 14b, and 31 squeezed-bark injuries on 25 trees in Subcompartment 14c. Most of the damage in the form of squeezed bark in both subcompartments was up to $200 \mathrm{~cm}^{2}$. In Subcompartment $14 \mathrm{~b}$, the area of the greatest damage was $1104 \mathrm{~cm}^{2}$, and a maximum of three individual injuries were recorded on one tree. In Subcompartment $14 \mathrm{c}$, the area of maximum damage was $695 \mathrm{~cm}^{2}$, and a maximum of two individual injuries were recorded on one tree. According to previous research, fungal infection on trees with squeezed bark is generally not expected, and such damage is significantly less than in peeled-bark injury;therefore this damage has not been analysed in detail in this paper.

\subsubsection{Peeled-Bark Injury}

Peeled-bark injury was the most common of all damage types. In Subcompartment $14 \mathrm{~b}, 859$ trees were recorded, and $33 \%$ of the trees had peeled-bark injuries. A total of 231 trees were recorded in Subcompartment 14c, and 39\% of the trees had peeled-bark injuries. Table 4 shows data per tree species. 
Table 4. Share of damaged trees.

\begin{tabular}{|c|c|c|c|c|c|c|c|}
\hline Subcompartment & & $\begin{array}{c}\text { Pedunculate } \\
\text { and Sessile Oak }\end{array}$ & $\begin{array}{c}\text { European } \\
\text { Beech }\end{array}$ & $\begin{array}{c}\text { European } \\
\text { Hornbeam }\end{array}$ & $\begin{array}{l}\text { Black } \\
\text { Alder }\end{array}$ & Other & $\sum$ \\
\hline \multirow{3}{*}{$14 b$} & Undamaged, N & 17 & 38 & 502 & 8 & 10 & 575 \\
\hline & $\begin{array}{l}\text { Trees with peeled } \\
\text { bark, } N(\%)\end{array}$ & $1(5.6 \%)$ & $5(11.6 \%)$ & $275(33.1 \%)$ & $2(20 \%)$ & $1(9.1 \%)$ & $284(33 \%)$ \\
\hline & $\sum$ & 18 & 43 & 777 & 10 & 11 & 859 \\
\hline \multirow{3}{*}{$14 \mathrm{c}$} & Undamaged, N & 3 & 64 & 73 & - & - & 140 \\
\hline & $\begin{array}{l}\text { Trees with peeled } \\
\text { bark, } N(\%)\end{array}$ & $3(50 \%)$ & $34(34.7 \%)$ & $54(42.5 \%)$ & - & - & $91(39 \%)$ \\
\hline & $\sum$ & 6 & 98 & 127 & - & - & 231 \\
\hline
\end{tabular}

\subsubsection{Position of the Damaged Trees in the Stand}

Considering the position of the tree in the stand relative to the transport infrastructure, in Subcompartment 14b, most of the total number of the damaged trees were located along the "ghost trails" (47\%), $8 \%$ was located along the main forwarding trail, and the rest $(45 \%)$ between the traffic infrastructure. In Subcompartment 14c, of the total number of damaged trees, $36 \%$ was situated along the harvester "ghost trails", $15 \%$ along the main forwarding trail, and the biggest share $(52 \%)$ in the stand between the traffic infrastructure. However, more importantly, according to the location of the tree in the stand, in both subcompartments most of the undamaged trees were in the stand between the traffic infrastructure, with 78\% in Subcompartment $14 \mathrm{~b}$ and $73 \%$ in Subcompartment 14c.

\subsubsection{Location of the Peeled-Bark Injury}

According to the location of the peeled-bark injury on the tree, in Subcompartment $14 \mathrm{~b}$, the most common were root collar injuries $(35 \%)$, followed by butt end $(34 \%)$, stem $(18 \%)$, and root injuries (13\%). In Subcompartment 14c, injuries were equally present on the root collar (36\%) and the butt end (36\%), then on the root $(16 \%)$ and the stem $(12 \%)$. Up to a level of $1.3 \mathrm{~m}$ from the ground, in Subcompartment $14 \mathrm{~b}$ there were $82 \%$ of all injuries, with $31 \%$ of them being greater than $100 \mathrm{~cm}^{2}$. In Subcompartment $14 \mathrm{c}, 88 \%$ of the injuries were found to a level of $1.3 \mathrm{~m}$ from the ground, with $44 \%$ of them being larger than $100 \mathrm{~cm}^{2}$.

\subsubsection{Magnitude of the Peeled-Bark Injury}

In Subcompartment 14b, injuries up to $100 \mathrm{~cm}^{2}$ were most common on the butt end $(38 \%)$ and the root collar (35\%). Overall, in the structure of the injuries, those with an area up to $100 \mathrm{~cm}^{2}$ prevailed (70\%). Injuries with an area of $101-500 \mathrm{~cm}^{2}$ were represented by $26 \%$ of the total number of injuries, and they were most common on the root collar (35\%). In the category of serious damage, i.e., larger than $501 \mathrm{~cm}^{2}$, there were only 34 injuries, or $4 \%$ of the total number of injuries, while the largest injury was present on the stem at a size of $4200 \mathrm{~cm}^{2}$. On one tree, the sum of the areas of all injuries was $7499 \mathrm{~cm}^{2}$, and a maximum of 14 injuries with an average size of $166.36 \mathrm{~cm}^{2}$ were recorded.

In Subcompartment 14c, injuries up to $100 \mathrm{~cm}^{2}$ were most common on the butt end $(47 \%)$; in the overall structure of the injuries, these were the most frequent (56\%). Injuries with an area of $101-500 \mathrm{~cm}^{2}$ were represented by $38 \%$ of the total number of injuries, and they were most present at the root collar $(41 \%)$. In the category of injuries larger than $501 \mathrm{~cm}^{2}$, there were 13 injuries, which was $6 \%$ of all injuries in the subcompartment. The greatest damage was present on the stem with an area of $2250 \mathrm{~cm}^{2}$, while on one tree, the sum of all injuries was $4101 \mathrm{~cm}^{2}$. A maximum of 12 injuries were recorded on one tree.

The influence of stand factors on the size of individual injuries in the form of peeled bark, as well as the sum of areas of peeled bark when using group work of harvesters and forwarders, were tested by a $t$-test whose parameters are shown in Table A4. The statistical test revealed a statistically significant difference in the size of the injury on the root collar 
between the subcompartments examined, by injury $(\mathrm{t}=-3.4912, p=0.0005)$ and by the sum of the areas of peeled bark per tree $(t=-2.4414, p=0.0154)$.

An analysis of variance and a Scheffé post hoc test revealed a statistically significant influence of the location of the tree in the stand in Subcompartment 14b on the sum of the size of the injury per tree $(\mathrm{F}=4.8721, p=0.0083)$. In Subcompartment $14 \mathrm{~b}$, the trees along the harvester "ghost trails" had a significantly larger area of peeled bark $\left(434 \mathrm{~cm}^{2}\right)$ than the trees in the stand between the traffic infrastructure $\left(215 \mathrm{~cm}^{2}\right)$. The trees along the main forwarding trail had an average $370 \mathrm{~cm}^{2}$ area of peeled bark. In addition, a statistically significant difference in the size of the peeled bark on the butt end $(\mathrm{F}=4.4440, p=0.0133)$ and the root collar $(\mathrm{F}=3.4585, p=0.0338)$ was found when comparing the injuries on the trees along the harvester "ghost trails" with the injuries on the trees located in the stand between the forest road infrastructure (Table A5). In contrast to the situation in Subcompartment $14 \mathrm{~b}$, the analysis of variance showed no statistically significant influence of the location of the tree in the stand on the sum of the size of the injury per tree $(\mathrm{F}=0.6789, p=0.5100)$. In Subcompartment 14c, the trees along the main forwarding trail had a $644 \mathrm{~cm}^{2}$ area of peeled bark, $394 \mathrm{~cm}^{2}$ along the harvester "ghost trails", and $408 \mathrm{~cm}^{2}$ for all other remaining trees in the stand. However, the results of the analysis of variance showed that there was a statistically significant effect of tree location on the size of peeled bark on the butt end $(\mathrm{F}=7.8601, p=0.0014)$ on trees located along the main forwarding trail in comparison with all other remaining trees (Table A5).

The number of injuries, the mean value of the injury area, the minimum and maximum injury area, and the standard deviation of the injury area are shown in Table 5 for individual injuries and summed on tree level by subcompartments and locations on the tree.

Table 5. Peeled bark magnitude on different locations on the tree.

\begin{tabular}{cccccc}
\hline & Valid N & Mean & Minimum & Maximum & Std. Dev. \\
\hline $14 \mathrm{bS}$ & 141 & 132.5 & 2 & 4200 & 375.9 \\
\hline $14 \mathrm{bS} \sum$ & 81 & 230.7 & 5 & 4200 & 513.1 \\
\hline $14 \mathrm{bB}$ & 269 & 96.2 & 2 & 1150 & 161.0 \\
\hline $14 \mathrm{bB} \sum$ & 155 & 166.9 & 2 & 1238 & 226.8 \\
\hline $14 \mathrm{bRc}$ & 276 & 107.6 & 2 & 1296 & 157.5 \\
\hline $14 \mathrm{bRc} \sum$ & 167 & 177.8 & 6 & 1428 & 245.6 \\
\hline $14 \mathrm{bR}$ & 107 & 171.7 & 6 & 858 & 157.2 \\
\hline $14 \mathrm{bR} \sum$ & 69 & 266.2 & 9 & 1941 & 312.5 \\
\hline $14 \mathrm{cS}$ & 26 & 205.5 & 6 & 2250 & 430.7 \\
\hline $14 \mathrm{cS} \sum$ & 15 & 356.1 & 6 & 2250 & 570.1 \\
\hline $14 \mathrm{cB}$ & 75 & 133.3 & 3 & 2050 & 279.2 \\
\hline $14 \mathrm{cB} \sum$ & 42 & 238.0 & 3 & 2738 & 450.9 \\
\hline $14 \mathrm{cRc}$ & 77 & 182.1 & 4 & 920 & 192.1 \\
\hline $14 \mathrm{cRc} \sum$ & 50 & 280.4 & 6 & 1462 & 306.5 \\
\hline $14 \mathrm{cR}$ & 34 & 219.3 & 10 & 750 & 184.6 \\
\hline $14 \mathrm{cR} \sum$ & 27 & 276.2 & 12 & 750 & 205.7 \\
\hline
\end{tabular}

S-stem, B-butt end, Rc—root colar, R-root. $\sum$-sum of the peeled bark area per tree in different locations on a tree.

\section{Discussion}

The most common type of damage to standing trees using a fully mechanised harvesterforwarder system in the subcompartments studied was peeled bark, followed by squeezed bark, but with a significantly lower intensity. In contrast, other forms of damage (uprooted and/or broken tree and broken branches) were almost absent. Similar results of the absence 
of crown damage were reported in the research on mechanised thinning of young coniferous stands [26].

The share of trees with peeled bark, expressed as a percentage of the number of remaining trees after finishing harvesting operations, was 33\% in Subcompartment 14b and 39\% in Subcompartment 14c. When compared with previous research on residual stand damage in mechanised thinning, the results are similar to those reported for young coniferous stands $(29.1-36.1 \%$ and $25 \%$ damaged trees) $[25,26]$ and for late thinnings of a mixed conifer stand (37.4\% of the remaining trees damaged) [29], but higher than $21.5 \%$ damaged trees in uneven-aged Norway spruce dominated stands [28] as well as $20.47 \%$ and $23.36 \%$ damaged trees in shelterwood-system regeneration felling of sessile oakdominated stands [30]. Previous research shows a wide range in the intensity of damage to the remaining trees in timber harvesting operations for the thinning of hardwoods (3-50\%) [23]. Interestingly, the results of this research are comparable to residual stand damage levels reported in the research on motor-manual felling and processing and mule $(38.0 \%$ and $45.6 \%$ of damaged trees) and tractor (39.6\% and $32.8 \%$ of damaged trees) extraction in the "Short Wood System" applied in the thinning from below of $20 \%$ volume in an even-aged beech high forest [47].

With regard to the cause of peeled-bark injury, the harvester in Subcompartment $14 \mathrm{c}$ damaged 18\% more trees than the forwarder, while in Subcompartment $14 \mathrm{~b}$ the harvester caused as much damage as the forwarder. This is opposed to the research results on the thinning of young Douglas-fir stands, where the harvester damaged more than twice as many residual trees than the forwarder [15]; it is also opposed to results from unevenaged Norway spruce dominated stands, where $88.4 \%$ of the damage was caused by an harvester and only $11.6 \%$ by a forwarder [28]. However, it was to the results reported for mechanised thinning in young coniferous stands [25]. In Subcompartment 14c, more trees were damaged during the harvester operation. This was most likely due to larger tree sizes, which made the handling of timber more difficult, especially since the hardwood assortments that were processed are ones for which specific harvester heads are still being developed [20]. Several research reports stress the fact that the most trunk damage occurred because of operations of selective thinning while pulling the felled trees for later processing on the "ghost trails" [25], the influence of off-trail felling and processing of large-diameter trees on the damage levels [15], and damage related to felling and moving stems while delimbing and processing [7]. Similar explanations can be applied when comparing the research results regarding the means of work and the location of the peeled-bark injury on the tree in Subcompartment 14c. Here, larger trees were felled and processed, and the harvester primarily damaged the butt end (56\% of the total number of injuries) with a statistically higher root collar damage in Subcompartment $14 \mathrm{c}$ than in Subcompartment $14 \mathrm{~b}$, and the forwarder primarily damaged the root collar $(59 \%$ of the total number of injuries). Moreover, significantly greater damage on the root collar (individual and sum of damage per tree) was found after forwarder work compared to the harvester in Subcompartment 14b. High shares of forwarder-caused damage to the root system (in relation to harvester-caused damage) were also reported for the thinning of young Douglasfir stands [15] and in research on mechanised harvesting of uneven-aged Norway spruce dominated stands, where all root damage was attributed to forwarder work [28]. Significant differences in the individual and sum per tree of root collar damage were found between the subcompartments, with greater damage in Subcompartment 14c. The results of this and previous research show that the greater number of damaged trees was influenced more by the dimensions of the assortments produced [9] than by the intensity of the felling $[9,10]$.

Different studies have yielded different classifications of injury severity, but all indicate the two most important parameters for assessing the severity of damage: injury depth and injury size $[9,10,31,34,48]$. The results of this research show a smaller number of trees with injuries in the category of serious damage $\left(>500 \mathrm{~cm}^{2}\right)-4 \%$ of all damaged trees in Subcompartment $14 \mathrm{~b}$ and $6 \%$ of all damaged trees in Subcompartment $14 \mathrm{c}$-in comparison 
with previous studies, where the prevalence of injuries in the category of serious damage was between 17-40\% in the use of partially mechanised harvesting systems [31,34].

Considering the size of the peeled bark, in both subcompartments the most common injuries were up to $100 \mathrm{~cm}^{2}$ (70\% in Subcompartment $14 \mathrm{~b}$ and $56 \%$ in Subcompartment $14 \mathrm{c})$, which are considered not to have major consequences for the stand [32,34,35].

Further reduction of the residual stand damage can be expected by changing the season of harvesting from the sap period (summertime, as in this research), when the probability of contact damage is reported to be 1.5 times higher than in other seasons and the damage area to be double compared to wintertime [7]. In addition, minimising damage could be achieved by the correct selection of harvesting machines and the improvement of working techniques [25]. In the case of this research, this would suggest a smaller harvester and forwarder, as well as further professional training in broadleaf stand thinning for harvester and forwarder operators who have previous experience mainly in harvesting coniferous plantations.

\section{Conclusions}

Factors influencing the amount and intensity of damage to standing trees during harvesting operations are numerous and intertwined. They should be identified during the organisation of a felling site, and their impact should be minimised. Therefore, during the planning phase of timber harvesting operations, sufficient attention should be paid to the choice of timber harvesting methods and systems to reduce overall damage to the stand (standing trees and forest soil). A special approach is required for stands in which a certain system is applied for the first time. One example is the proper design of "ghost trails", which can be a challenge in late thinnings and can affect the level of damage compared with the stands that were designated for mechanised thinning from early thinnings onward and for which appropriate forest infrastructure for mechanised harvesting is already established. Certainly, it is necessary to have a well-trained operator, who, as one of the variables that can be influenced, can reduce the damage to the stand.

The results of the research point to the fact that the factors influencing the occurrence of damage to the standing trees cannot be unambiguously determined, and that they involve a combination of various factors, such as stand characteristics, structure of trees marked for felling, tree dimensions, dimensions of machines used, operator work techniques and skills, etc. The reported values in the category of serious damage together with the prevailing share of peeled-bark injuries below $100 \mathrm{~cm}^{2}$ should limit damage-related economic losses in the stand, keeping in mind that most of the damage occurred on the European hornbeam trees (more evident in Subcompartment 14b following the growing stock composition). However, prior to application of the harvesting system researched to oak-dominated stands or to mixed stands with a high share of tree species that produce high-value timber assortments, appropriate residual-stand damage-mitigation strategies should be applied.

As the fully mechanised harvesting system that has been researched occupies an increasing share in timber production with the expected growth trend, it would be desirable to standardize methods for determining and reporting damage to stands, with a special emphasis on the maximum allowable degree of damage to broadleaf stands. This would lead to a reference value for assessing the quality of the work performed and for planning further management. 
Author Contributions: Conceptualization, D.V. and T.P.; methodology, D.V. and T.P.; validation, A.Đ. and Ž.Z.; formal analysis, D.V. and B.U.; investigation, D.V., I.P. and B.U.; writing-original draft preparation, B.U., D.V. and I.P.; writing-review and editing, A.Đ., T.P. and Ž.Z.; visualization, A.Đ. and I.P.; supervision, D.V. All authors have read and agreed to the published version of the manuscript.

Funding: The research was funded by the Ministry of Agriculture of the Republic of Croatia with funds for the compensation for the use of non-market forest functions (OKFŠ) within the Project Optimization of timber harvesting systems and forest traffic infrastructure at a strategic-tactical planning level.

Data Availability Statement: Data supporting this study may be provided upon reasonable request to the authors of the study.

Acknowledgments: The authors thank the company Croatian forests Ltd. and the company Šumarske usluge vl. Stjepan Žilić for assistance in organizing and conducting field harvesting trials.

Conflicts of Interest: The authors declare no conflict of interest.

\section{Appendix A. Statistical Analyses Results}

Table A1. Injury magnitude (harvester-caused) vs. stand factor $t$-test results.

\begin{tabular}{|c|c|c|c|c|c|c|c|c|c|c|c|}
\hline & $\begin{array}{l}\text { Mean } \\
\text { Group } 1\end{array}$ & $\begin{array}{c}\text { Mean } \\
\text { Group } 2\end{array}$ & t-Value & df & $p$ & $\begin{array}{l}\text { Valid N } \\
\text { Group } 1\end{array}$ & $\begin{array}{l}\text { Valid N } \\
\text { Group } 2\end{array}$ & $\begin{array}{l}\text { Std.Dev. } \\
\text { Group } 1\end{array}$ & $\begin{array}{l}\text { Std.Dev. } \\
\text { Group } 2\end{array}$ & $\begin{array}{l}\text { F-Ratio } \\
\text { Variances }\end{array}$ & $\begin{array}{c}p \\
\text { Variances }\end{array}$ \\
\hline $\begin{array}{l}14 \mathrm{bSH} \text { vs. } \\
14 \mathrm{cSH}\end{array}$ & 91.50 & 97.00 & -0.11 & 18 & 0.9114 & 6 & 14 & 103.58 & 98.36 & 1.11 & 0.8043 \\
\hline $\begin{array}{l}\text { 14bSH } \sum v s . \\
14 \mathrm{c} S \sum\end{array}$ & 109.80 & 194.00 & -0.77 & 10 & 0.4613 & 5 & 7 & 105.83 & 226.38 & 4.58 & 0.1627 \\
\hline $\begin{array}{c}14 \mathrm{bBH} \text { vs. } \\
14 \mathrm{cBH}\end{array}$ & 103.56 & 120.59 & -0.39 & 55 & 0.6979 & 18 & 39 & 175.36 & 142.19 & 1.52 & 0.2786 \\
\hline $\begin{array}{c}\text { 14bBH } \sum \text { vs. } \\
14 \mathrm{cBH} \sum\end{array}$ & 169.45 & 188.28 & -0.29 & 34 & 0.7736 & 11 & 25 & 206.14 & 167.10 & 1.52 & 0.3840 \\
\hline $\begin{array}{l}\text { 14bRcH vs. } \\
\text { 14cRcH }\end{array}$ & 76.97 & 165.71 & -2.43 & 47 & 0.0190 & 32 & 17 & 74.66 & 180.78 & 5.86 & 0.0000 \\
\hline $\begin{array}{l}\text { 14bRcH } \sum \text { vs. } \\
14 \mathrm{c} \text { RcH } \sum\end{array}$ & 102.63 & 201.21 & -1.81 & 36 & 0.0791 & 24 & 14 & 93.13 & 239.90 & 6.64 & 0.0001 \\
\hline $\begin{array}{l}\text { 14bRH vs. } \\
\text { 14cRH }\end{array}$ & 0.00 & 0.00 & & -2 & & 0 & 0 & 0.00 & 0.00 & & \\
\hline $\begin{array}{c}\text { 14bRH } \sum \text { vs. } \\
14 \mathrm{cRH} \sum\end{array}$ & 0.00 & 0.00 & & -2 & & 0 & 0 & 0.00 & 0.00 & & \\
\hline
\end{tabular}

S-stem, B-butt end, Rc—root colar, R-root, H-harvester. $\sum$-sum of the peeled-bark area per tree in different locations on a tree. Statistically significant differences $(p<0.05)$ marked in red.

Table A2. Injury magnitude (forwarder-caused) vs. stand factor $t$-test results.

\begin{tabular}{cccccccccccc}
\hline & $\begin{array}{c}\text { Mean } \\
\text { Group 1 }\end{array}$ & $\begin{array}{c}\text { Mean } \\
\text { Group 2 }\end{array}$ & t-Value & df & $p$ & $\begin{array}{c}\text { Valid N } \\
\text { Group 1 }\end{array}$ & $\begin{array}{c}\text { Valid N } \\
\text { Group 2 }\end{array}$ & $\begin{array}{c}\text { Std.Dev. } \\
\text { Group 1 }\end{array}$ & $\begin{array}{c}\text { Std.Dev. } \\
\text { Group 2 }\end{array}$ & $\begin{array}{c}\text { F-Ratio } \\
\text { Variances }\end{array}$ & $\begin{array}{c}p \\
\text { Variances }\end{array}$ \\
\hline $\begin{array}{c}\text { 14bSF vs. } \\
14 \mathrm{cSF}\end{array}$ & 185.00 & 185.25 & -0.0027 & 5 & 0.9979 & 3 & 4 & 153.05 & 94.01 & 2.65 & 0.4345 \\
\hline $\begin{array}{c}14 \mathrm{bSF} \sum \text { vs. } \\
14 \mathrm{c} \text { SF } \sum\end{array}$ & 277.50 & 247.00 & 0.2221 & 3 & 0.8385 & 2 & 3 & 95.46 & 171.40 & 3.22 & 0.7328 \\
\hline $\begin{array}{c}14 \mathrm{bBF} \text { vs. } \\
14 \mathrm{cBF}\end{array}$ & 151.32 & 261.71 & -0.8183 & 31 & 0.4194 & 19 & 14 & 152.64 & 563.52 & 13.63 & 0.0000 \\
\hline $\begin{array}{c}14 \mathrm{bBF} \sum \text { vs. } \\
14 \mathrm{cBF} \sum\end{array}$ & 205.36 & 366.40 & -0.7692 & 22 & 0.4500 & 14 & 10 & 151.13 & 769.45 & 25.92 & 0.0000 \\
\hline $\begin{array}{c}14 \mathrm{bRcF} \text { vs. } \\
14 \mathrm{cRcF}\end{array}$ & 223.06 & 193.42 & 0.4882 & 56 & 0.6273 & 32 & 26 & 266.04 & 175.16 & 2.31 & 0.0353 \\
\hline
\end{tabular}


Table A2. Cont.

\begin{tabular}{cccccccccccc}
\hline & $\begin{array}{c}\text { Mean } \\
\text { Group 1 }\end{array}$ & $\begin{array}{c}\text { Mean } \\
\text { Group 2 }\end{array}$ & t-Value & df & $p$ & $\begin{array}{c}\text { Valid N } \\
\text { Group 1 }\end{array}$ & $\begin{array}{c}\text { Valid N } \\
\text { Group 2 }\end{array}$ & $\begin{array}{c}\text { Std.Dev. } \\
\text { Group 1 }\end{array}$ & $\begin{array}{c}\text { Std.Dev. } \\
\text { Group 2 }\end{array}$ & $\begin{array}{c}\text { F-Ratio } \\
\text { Variances }\end{array}$ & $\begin{array}{c}p \\
\text { Variances }\end{array}$ \\
\hline $\begin{array}{c}\text { 14bRcF } \sum v s . \\
\text { 14cRcF } 5\end{array}$ & 356.90 & 295.82 & 0.5189 & 35 & 0.6071 & 20 & 17 & 426.51 & 249.88 & 2.91 & 0.0353 \\
\hline $\begin{array}{c}\text { 14bRFvs. } \\
\text { 14cRF }\end{array}$ & 275.25 & 0.00 & & 2 & & 4 & 0 & 127.11 & 0.00 & 0 & 1.0000 \\
\hline $\begin{array}{c}14 \mathrm{bRF} \sum \text { vs. } \\
\text { 14cRF } 5\end{array}$ & 275.25 & 0.00 & & 2 & & 4 & 0 & 127.11 & 0.00 & 0 & 1.0000 \\
\hline
\end{tabular}

S-stem, B-butt end, Rc-root colar, R-root, F-forwarder. $\sum$-sum of the peeled-bark area per tree in different locations on a tree.

Table A3. Injury magnitude vs. means of work (in the same stand) $t$-test results.

\begin{tabular}{|c|c|c|c|c|c|c|c|c|c|c|c|}
\hline & $\begin{array}{c}\text { Mean } \\
\text { Group } 1 \\
\end{array}$ & $\begin{array}{c}\text { Mean } \\
\text { Group } 2 \\
\end{array}$ & t-Value & df & $p$ & $\begin{array}{l}\text { Valid N } \\
\text { Group } 1 \\
\end{array}$ & $\begin{array}{l}\text { Valid N } \\
\text { Group } 2 \\
\end{array}$ & $\begin{array}{l}\text { Std.Dev. } \\
\text { Group } 1 \\
\end{array}$ & $\begin{array}{l}\text { Std.Dev. } \\
\text { Group } 2 \\
\end{array}$ & $\begin{array}{c}\text { F-Ratio } \\
\text { Variances }\end{array}$ & $\begin{array}{c}p \\
\text { Variances }\end{array}$ \\
\hline $\begin{array}{c}\text { 14bSH vs. } \\
14 \mathrm{bSF}\end{array}$ & 91.50 & 185.00 & -1.1036 & 7 & 0.3063 & 6 & 3 & 103.58 & 153.05 & 2.1834 & 0.4164 \\
\hline $\begin{array}{c}14 \mathrm{bSH} \sum \mathrm{vs} . \\
14 \mathrm{bSF} \sum\end{array}$ & 109.80 & 277.50 & -1.9304 & 5 & 0.1114 & 5 & 2 & 105.83 & 95.46 & 1.2290 & 1.0000 \\
\hline $\begin{array}{c}14 \mathrm{bBH} \text { vs. } \\
14 \mathrm{bBF}\end{array}$ & 103.56 & 151.32 & -0.8850 & 35 & 0.3822 & 18 & 19 & 175.36 & 152.64 & 1.3199 & 0.5642 \\
\hline $\begin{array}{c}\text { 14bBH } \sum \text { vs. } \\
14 \mathrm{bBF} \sum\end{array}$ & 169.45 & 205.36 & -0.5030 & 23 & 0.6198 & 11 & 14 & 206.14 & 151.13 & 1.8605 & 0.2924 \\
\hline $\begin{array}{c}\text { 14bRcH vs. } \\
14 \mathrm{bRcF}\end{array}$ & 76.97 & 223.06 & -2.9909 & 62 & 0.0040 & 32 & 32 & 74.66 & 266.04 & 12.6958 & 0.0000 \\
\hline $\begin{array}{c}\text { 14bRcH } \sum \text { vs. } \\
\text { 14bRcF } \sum\end{array}$ & 102.63 & 356.90 & -2.8467 & 42 & 0.0068 & 24 & 20 & 93.13 & 426.51 & 20.9721 & 0.0000 \\
\hline $\begin{array}{l}\text { 14bRH vs. } \\
14 \mathrm{bRF}\end{array}$ & 0.00 & 275.25 & & 2 & & 0 & 4 & 0.00 & 127.11 & 0.0000 & 1.0000 \\
\hline $\begin{array}{c}\text { 14bRH } \sum \text { vs. } \\
14 \mathrm{bRF} \sum\end{array}$ & 0.00 & 275.25 & & 2 & & 0 & 4 & 0.00 & 127.11 & 0.0000 & 1.0000 \\
\hline $\begin{array}{c}14 \mathrm{cSH} \text { vs. } \\
14 \mathrm{cSF}\end{array}$ & 97.00 & 185.25 & -1.5955 & 16 & 0.1302 & 14 & 4 & 98.36 & 94.01 & 1.0947 & 1.0000 \\
\hline $\begin{array}{l}\text { 14cSH } \sum \text { vs. } \\
14 \mathrm{cSF} \sum\end{array}$ & 194.00 & 247.00 & -0.3590 & 8 & 0.7289 & 7 & 3 & 226.38 & 171.40 & 1.7443 & 0.8164 \\
\hline $\begin{array}{c}14 \mathrm{cBH} \text { vs. } \\
14 \mathrm{cBF}\end{array}$ & 120.59 & 261.71 & -1.4619 & 51 & 0.1499 & 39 & 14 & 142.19 & 563.52 & 15.7077 & 0.0000 \\
\hline $\begin{array}{l}14 \mathrm{cBH} \sum \mathrm{vs} . \\
14 \mathrm{cBF} \sum\end{array}$ & 188.28 & 366.40 & -1.1166 & 33 & 0.2722 & 25 & 10 & 167.10 & 769.45 & 21.2033 & 0.0000 \\
\hline $\begin{array}{l}\text { 14cRcH vs. } \\
\text { 14cRcF }\end{array}$ & 165.71 & 193.42 & -0.5010 & 41 & 0.6191 & 17 & 26 & 180.78 & 175.16 & 1.0652 & 0.8639 \\
\hline $\begin{array}{l}\text { 14cRcH } \sum \text { vs. } \\
14 \mathrm{cRcF} \sum\end{array}$ & 201.21 & 295.82 & -1.0680 & 29 & 0.2943 & 14 & 17 & 239.90 & 249.88 & 1.0849 & 0.8941 \\
\hline $\begin{array}{l}\text { 14cRH vs. } \\
14 \mathrm{cRF}\end{array}$ & 0.00 & 0.00 & & -2 & & 0 & 0 & 0.00 & 0.00 & & \\
\hline $\begin{array}{l}\text { 14cRH } \sum \text { vs. } \\
14 \mathrm{cRF} \sum\end{array}$ & 0.00 & 0.00 & & -2 & & 0 & 0 & 0.00 & 0.00 & & \\
\hline
\end{tabular}

S-stem, B-butt end, Rc-root collar, R-root, H-harvester, F-forwarder. $\sum$-sum of the peeled-bark area per tree in different locations on a tree. Statistically significant differences $(p<0.05)$ marked in red. 
Table A4. Injury magnitude vs. stand factors $t$-test results.

\begin{tabular}{|c|c|c|c|c|c|c|c|c|c|c|c|}
\hline & $\begin{array}{l}\text { Mean } \\
\text { Group } 1\end{array}$ & $\begin{array}{c}\text { Mean } \\
\text { Group } 2\end{array}$ & t-Value & $\mathrm{df}$ & $p$ & $\begin{array}{l}\text { Valid N } \\
\text { Group } 1\end{array}$ & $\begin{array}{l}\text { Valid N } \\
\text { Group } 2\end{array}$ & $\begin{array}{l}\text { Std.Dev. } \\
\text { Group } 1\end{array}$ & $\begin{array}{l}\text { Std.Dev. } \\
\text { Group } 2\end{array}$ & $\begin{array}{c}\text { F-Ratio } \\
\text { Variances }\end{array}$ & $\begin{array}{c}p \\
\text { Variances }\end{array}$ \\
\hline $14 \mathrm{bS}$ vs. $14 \mathrm{cS}$ & 132.52 & 205.46 & -0.8883 & 165 & 0.3757 & 141 & 26 & 375.89 & 430.72 & 1.3130 & 0.3259 \\
\hline $\begin{array}{c}14 \mathrm{bS} \sum \mathrm{vs} . \\
14 \mathrm{cS} \sum\end{array}$ & 230.69 & 356.13 & -0.8549 & 94 & 0.3948 & 81 & 15 & 513.15 & 570.08 & 1.2342 & 0.5362 \\
\hline $\begin{array}{c}14 \mathrm{bB} \text { vs. } \\
14 \mathrm{cB}\end{array}$ & 96.17 & 133.29 & -1.4744 & 342 & 0.1413 & 269 & 75 & 161.00 & 279.23 & 3.0078 & 0.0000 \\
\hline $\begin{array}{c}14 \mathrm{bB} \sum \mathrm{vs} . \\
14 \mathrm{cB} \sum\end{array}$ & 166.90 & 238.02 & -1.4160 & 195 & 0.1584 & 155 & 42 & 226.80 & 450.94 & 3.9532 & 0.0000 \\
\hline $\begin{array}{c}\text { 14bRc vs. } \\
14 \mathrm{cRc}\end{array}$ & 107.57 & 182.09 & -3.4912 & 351 & 0.0005 & 276 & 77 & 157.50 & 192.12 & 1.4879 & 0.0227 \\
\hline $\begin{array}{c}\text { 14bRc } \sum \text { vs. } \\
14 \mathrm{cRc} \sum\end{array}$ & 177.78 & 280.42 & -2.4414 & 215 & 0.0154 & 167 & 50 & 245.65 & 306.52 & 1.5570 & 0.0417 \\
\hline $\begin{array}{c}\text { 14bR vs. } \\
14 \mathrm{cR}\end{array}$ & 266.25 & 276.19 & -0.1526 & 94 & 0.8791 & 69 & 27 & 312.52 & 205.73 & 2.3076 & 0.0199 \\
\hline $\begin{array}{c}\text { 14bR } \sum \text { vs. } \\
14 \mathrm{c} \sum \sum\end{array}$ & 266.25 & 276.19 & -0.1526 & 94 & 0.8791 & 69 & 27 & 312.52 & 205.73 & 2.3076 & 0.0199 \\
\hline
\end{tabular}

S-stem, B-butt end, Rc—root collar, R-root. $\sum$-sum of the peeled-bark area per tree in different locations on a tree. Statistically significant differences $(p<0.05)$ marked in red.

Table A5. Analysis of the variance of the influence of the tree location on the total size of the injury (peeled bark) per tree.

\begin{tabular}{ccccccccc}
\hline & SS Effect & df Effect & MS Effect & SS Error & df Error & MS Error & F & $p$ \\
\hline $14 \mathrm{bS}$ & 669854 & 2 & 334927 & 20350732 & 77 & 264295.2 & 1.2672 & 0.2874 \\
\hline $14 \mathrm{bB}$ & 437602 & 2 & 218801 & 7483819 & 152 & 49235.6 & 4.4440 & 0.0133 \\
\hline $14 \mathrm{bRc}$ & 405392 & 2 & 202696 & 9611604 & 164 & 58607.3 & 3.4585 & 0.0338 \\
\hline $14 \mathrm{bR}$ & 88734 & 2 & 44367 & 6552689 & 66 & 99283.2 & 0.4469 & 0.6415 \\
\hline $14 \mathrm{~b} \sum$ & 3142156 & 2 & 1571078 & 88999703 & 276 & 322462.7 & 4.8721 & 0.0083 \\
\hline $14 \mathrm{cS}$ & 232730 & 2 & 116365 & 4317072 & 12 & 359756.0 & 0.3235 & 0.7298 \\
\hline $14 \mathrm{cB}$ & 2395113 & 2 & 1197556 & 5941986 & 39 & 152358.6 & 7.8601 & 0.0014 \\
\hline $14 \mathrm{cRc}$ & 740 & 2 & 370 & 4603150 & 47 & 97939.4 & 0.0038 & 0.9962 \\
\hline $14 \mathrm{cR}$ & 130389 & 2 & 65195 & 970057 & 24 & 40419.0 & 1.6130 & 0.2202 \\
\hline $14 \mathrm{c} \sum$ & 563651 & 2 & 281825 & 34040275 & 82 & 415125.3 & 0.6789 & 0.5100 \\
\hline
\end{tabular}

S-stem, B-butt end, Rc-root collar, R-root, $\sum$-sum of the peeled-bark area per tree. Statistically significant differences $(p<0.05)$ marked in red.

\section{References}

1. Anić, I. Uzgajanje Šuma I; Šumarski Fakultet Sveučilišta u Zagrebu: Zagreb, Croatia, 2017; p. 37.

2. Čavlović, J. Osnove Uređivanja Šuma; Šumarski Fakultet Sveučilišta u Zagrebu: Zagreb, Croatia, 2013; p. 50.

3. Poršinsky, T.; Ožura, M. Oštećivanje dubećih stabala pri izvoženju drva forvarderom. Nova Meh. Šumarstva 2006, 27, 41-49.

4. Martinić, I. Interakcije Metoda Rada, Radnih Uvjeta i Proizvodnosti Rada pri Sječi i Izradi Drva u Proredama Sastojina. Master's, Thesis, Šumarski Fakultet u Zagrebu, Zagreb, Croatia, 1990.

5. Tomanić, S.; Vondra, V.; Martinić, I. Oštećenje sastojina pri šumskim radovima (Damage on Stands at Forest Work). Meh. Šumarstva $1989,14,65-72$.

6. Athanassiadis, D. Residual stand damage following cut-to-length harvesting operations with a farm tractor in two conifer stands. Silva Fenn. 1997, 31, 461-467. [CrossRef]

7. Siren, M. Tree Damage in Single-Grip Harvester Thinning Operations. J. For. Eng. 2001, 12, 29-38.

8. Martinić, I. Oštećivanje sastojine pri obaranju stabala, izradi i privlačenju drva. Šumarski List 1991, 115, 33-47.

9. Sist, P.; Nolan, T.; Bertault, J.G.; Dykstra, D. Harvesting intensity versus sustainability in Indonesia. For. Ecol. Manag. 1998, 108, 251-260. [CrossRef]

10. Behjou, F.K. Effects of wheeled cable skidding on residual trees in selective logging in Caspian forests. Small-Scale For. 2014, 13, 367-376. [CrossRef] 
11. Limbeck-Lilienau, B. Residual stand damage caused by mechanized harvesting systems. In Proceedings of the Austro 2003 meeting: High Tech Forest Operations for Mountainous Terrain, Schlaegl, Austria, 5-9 October 2003.

12. Iskandar, H.; Snook, L.K.; Toma, T.; MacDicken, K.; Kanninen, M. A comparison of damage due to logging under different forms of resource access in East Kalimantan, Indonesia. For. Ecol. Manag. 2006, 237, 83-93. [CrossRef]

13. Pinard, M.A.; Putz, F.E. Retaining forest biomass by reducing logging damage. Biotropica 1996, 28, 278-295. [CrossRef]

14. Picchio, R.; Tavankar, F.; Bonyad, A.; Mederski, P.S.; Venanzi, R.; Nikooy, M. Detailed analysis of residual stand damage due to winching on steep terrains. Small-Scale For. 2019, 18, 255-277. [CrossRef]

15. Han, H.S.; Kellogg, L.D. Damage characteristics in young Douglas-fir stand from commercial thinning with four Timber harvesting systems. West. J. Appl. For. 2000, 15, 27-33. [CrossRef]

16. Pinard, M.A.; Putz, F.E.; Tay, J.; Sullivan, T.E. Creating timber harvesting guidelines for a reduced impact logging project in Malaysia. J. For. 1995, 39, 41-45.

17. Spinelli, R.; Magagnotti, N.; Schweier, J. Trends and perspectives in coppice harvesting. Croat. J. For. Eng. 2017, 38, $219-230$.

18. Lopes, E.S.; Diniz, C.C.C.; Serpe, E.L.; Cabral, O.M.J.V. Efeito do sortimento da madeira na produtividade e custo do forwarder no desbaste comercial de Pinus taeda. Sci. For. 2016, 44, 57-66. [CrossRef]

19. Spinelli, R.; Nati, C.A. Low-Investment fully mechanised operation for pure selection thinning of pine plantations. Croat. J. For Eng. 2009, 30, 8-97.

20. Mederski, P.S.; Borz, S.A.; Đuka, A.; Lazdinš, A. Challenges in Forestry and Forest Engineering-Case Studies from Four Countries in East Europe. Croat. J. For. Eng. 2021, 42, 117-134. [CrossRef]

21. Vusić, D.; Rukavina, N. Utjecaj rašljavosti stabala crnoga bora na proizvodnost harvestera. Nova Meh. Šumarstva 2010, 31, 37-43

22. Spinelli, R.; Magagnotti, N.; Labelle, E.R. The effect of new silvicultural trends on mental workload of harvester operators. Croat. J. For. Eng. 2020, 41, 1-13. [CrossRef]

23. Picchio, R.; Mederski, P.S.; Tavankar, F. How and how much, do harvesting activities affect forest soil, regeneration and stands? Curr. For. Rep. 2020, 6, 115-128. [CrossRef]

24. Košir, B. Modeling stand damage and comparison of two harvesting methods. Croat. J. For. Eng. 2008, 29 , 5-14.

25. Lopes, E.S.; Oliveira, F.S.; Droog, E.A. Damage to residual trees following commercial thinning by harvester and forwarder in a Pinus taeda stand in Southern Brazil. Sci. For. 2018, 46, 167-175. [CrossRef]

26. Diniz, C.C.C.; de Oliveira, F.M.; Junior, R.T.; Robert, R.C.G.; Tramontini, M.P.; de Brito, F.B. Damage caused by a wheeled harvester to the residual trees of a pinus stand in the first mechanized mixed thinning. Floresta 2020, 50, 1547-1554. [CrossRef]

27. Holzleitner, F.; Langmaier, M.; Hochbichler, E.; Obermayer, B.; Stampfer, K.; Kanzian, C. Effect of prior tree marking, thinning method and topping diameter on harvester performance in a first thinning operation-A field experiment. Silva Fenn. 2019, 53, 22. [CrossRef]

28. Sirén, M.; Hyvönen, J.; Surakka, H. Tree Damage in Mechanized Uneven-aged Selection Cuttings. Croat. J. For. Eng. 2015, 36, 33-42.

29. Froese, K.; Han, S.H. Residual Stand Damage from Cut-to-Length Thinning of a Mixed Conifer Stand in Northern Idaho. West. J. Appl. For. 2006, 21, 142-148. [CrossRef]

30. Dudáková, Z.; Allman, M.; Meranič, J.; Meganičová, K. Machinery-Induced Damage to Soil and Remaining Forest Stands-Case Study from Slovakia. Forests 2020, 11, 15.

31. Vuletić, D. Ekonomski Gubici na Vrijednosti Drva Hrasta Lužnjaka (Quercus robur L.) kao Posljedica Ozljeđivanja Stabala. Master's, Thesis, Šumarski Fakultet u Zagrebu, Zagreb, Croatia, 1996.

32. Meng, W. Baumverletzungen durch Transportvorgänge bei der Holzermte-Ausmaß und Verteilung, Folgeschäden am Holz und Versuch ihrer Bewertung. Schr. Der LFV Baden-Württemberg 1978, 53, 159.

33. Butora, A.; Schwager, G. Holzernteschäden in Durchforstungsbeständen. Ber. Der Eidgenössischen Anst. Für Das Forstl. Vers. Schweiz 1986, 288, 47.

34. Krpan, A.P.B.; Petreš, S.; Ivanović, Ž. Neke fizičke štete u sastojini, posljedice i zaštita (Forest stand damage, effects and protection). Glas. Za Šumske Pokuse 1993, Special edition 4, 271-279.

35. Doležal, B. Štete u Šumi Izazvane Mehanizacijom; Jugoslavenski Poljoprivredno Šumarski Centar: Beograd, Serbia, $1984 ;$ pp. 1-47.

36. Smith, H.C.; Miller, G.W.; Schuler, T.M. Closure of Logging Wounds after 10 Years; Research Paper; USDA Forest ServiceNortheastern Forest Experiment Station: Radnor, PA, USA, 1994; Volume 692, pp. 1-10.

37. Bettinger, P.; Kellogg, L.D. Residual stand damage from cut-to-length thinning of second-growth timber in the Cascade Range of western Oregon. For. Prod. J. 1993, 43, 59-64.

38. Bragg, W.C.; Ostrofsky, W.D.; Hoffman, B.F. Residual tree damage estimates from partial cutting simulation. For. Prod. J. 1994, 44, 19-22.

39. Tavankar, P.; Bonyad, A.; Marchi, E.; Venanzi, R.; Picchio, R. Effect of logging wounds on diameter growth of beech (Fagus orientalis Lipsky) trees following selection cutting in Caspian forests of Iran. N. Z. J. For. Sci. 2015, 45, 19. [CrossRef]

40. Kiser, J. Histochemical and geometric alterations of sapwood in coastal Douglas-fir following mechanical damage during commercial thinning. Silva Fenn. 2011, 45, 729-741. [CrossRef]

41. Glavaš, M. Gljivične Bolesti Šumskog Drveća; Šumarski Fakultet Sveučilišta u Zagrebu: Zagreb, Croatia, 1999 ; pp. 54-56.

42. Arač, K.; Kranjec Orlović, J.; Diminić, D. Effect of Fungus Meripilus giganteus (Pers.) P. Karst. On Occurrence and Develompment of False Heartwood and Rot in Fagus sylvatica L. Round Wood. Croat. J. For. Eng. 2021, 42, 529-542. [CrossRef] 
43. Filip, G.M. Managing Tree Wounding and Stem Decay in Oregon Forests; The Woodland Workbook EC 1519, Extension ServiceOregon State University: Corvallis, OR, USA, 2001; pp. 1-3.

44. Bobik, M. Damages to Residual Stand in Commercial Thinnings. Master's Thesis, Swedish University of Agricultural Sciences, Southern Swedish Forest Research Centre, Uppsala, Sweden, 2008.

45. Marchi, E.; Chung, W.; Visser, R.; Abbas, D.; Nordfjell, T.; Mederski, P.S.; McEwan, A.; Brink, M.; Laschi, A. Sustainable Forest Operations (SFO): A new paradigm in a changing world and climate. Sci. Total Environ. 2018, 634, 1385-1397. [CrossRef] [PubMed]

46. NN, 1997: Pravilnik o Uređivanju Šuma. Narodne Novine, NN 11/1997. Available online: https://narodne-novine.nn.hr/clanci/ sluzbeni/1997_01_11_171.html (accessed on 5 November 2021).

47. Venanzi, R.; Barbona, L.; Latterini, F.; Picchio, R. Disturbs to the Ground and to the Stand in Beech Forest due to Thninning Tretment Performed by Different Levels of Mechanization. Enviromental Sci. Proc. 2019, 3, 58. [CrossRef]

48. Lavallee, A.; Lortie, M. Relationships between external features and trunk rot in living yellow birch. For. Chron. 1968, 44, 5-10. [CrossRef] 